\title{
Marginal Part-Time Employment in Indonesian Labor Market: Profile and Determinant
}

\author{
Dede Mahmuda \\ Universitas Indonesia, Indonesia, dedemahmuda.dm@gmail.com
}

\begin{abstract}
The increase of marginal part-time employment has been found in developed countries, as well as in developing countries. This form of non-standard employment has very short work hours (less than 15 hours/week) and no guarantee of stable employment. In Indonesia, the share of part-time worker amongst working population increased from 15.4 percent in 2009 to 22.1 percent in 2018 . Unfortunately, few studies discuss about marginal part-time employment. Using binary logistic regression, this study aims to identify marginal part-time workers based on their socio-demographic characteristic. The result indicates that female (OR: 1.81; 95\% CI: 1.75-1.87), living in rural area (OR: 1.12; 95\% CI: 1.08-1.16), and less educated are more likely to be marginal part-timer. Therefore, it is recommended for policymakers to ensure the labor regulation adequately protect the rights of part-time worker, so that the workers condition can be improved since they are most vulnerable group in the globalized economy.
\end{abstract}

Keywords: non-standard employment, labor market, part-time, Indonesia

\section{Pekerja Paruh Waktu Marjinal Pada Pasar Tenaga Kerja Indonesia: Profil dan Determinan}

\begin{abstract}
Abstrak
Peningkatan pekerja paruh waktu marjinal telah teramati pada negara-negara maju dan juga negara berkembang. Salah satu bentuk pekerjaan non-standar ini memiliki jam kerja yang sangat pendek (kurang dari 15 jam seminggu) dan tidak adanya jaminan kestabilan pekerjaan. Di Indonesia, proporsi pekerja paruh waktu diantara penduduk bekerja meningkat dari 15,4 persen pada 2009 menjadi 22,1 persen pada 2018. Sayangnya, hanya sedikit studi yang membahas tentang pekerjaan paruh waktu marjinal. Dengan menggunakan regresi logistik biner, studi ini bertujuan untuk mengidentifikasi pekerja paruh waktu marjinal berdasarkan karakteristik sosio-demografinya. Hasil menunjukkan bahwa perempuan (OR: 1,81; 95\% CI: 1,75-1,87), penduduk desa (OR: 1,12; 95\% CI: 1,08-1,16), dan kurang berpendidikan berisiko lebih besar menjadi pekerja paruh waktu marjinal. Oleh karena itu, direkomendasikan bagi pembuat kebijakan untuk dapat memastikan peraturan ketenagakerjaan cukup untuk melindungi hak-hak pekerja paruh waktu khusus yang termarjinal agar kondisi pekerja dapat ditingkatkan karena mereka adalah kelompok paling rentan dalam ekonomi global.
\end{abstract}

Kata kunci: pekerjaan non-standar, pasar tenaga kerja, paruh waktu, Indonesia

\section{INTRODUCTION}

The globalized economy stemmed from the combination of rapid technological and economic changes brought some consequences, one of those is the growth of non-standard employment (NSE) or precarious work around the world. Researchers differ in defining NSE, for some instance it will be referred to the definition of standard employment relationship as occurring at a set place of work outside the home. This characteristic makes an even broader scope of tasks to be included in NSE. One of the most important definitions offered by Pfeffer \& Baron (1988), categorized non-standard workers into three broad 
groups: (1) those who have a limited temporal attachment to organization, such as temporary and part-time workers, (2) those who have a limited physical attachment to the organization, such as teleworkers or those who work at home, and (3) those with limited administrative attachment to the organization, such as independent contractors (Chattopadhyay, 2017). In addition, Houseman \& Osawa (2003) gave more specific classification as they referred non-standard work as jobs that are not full-time paid employment of unlimited duration including part-time work, contingent work, and selfemployment.

One of NSE's form is part-time employment which is usually considered as working fewer than 35 hours, or 30 hours, per week (Champeau et al., 2016). In fact, increasing trend of part-time workers with working hours of less than 15 hours per week has been widely observed in developed countries. Workers with very short working hours are called marginal part-time workers. ILO data from 2005 to 2013 in OECD countries shows that there's a tendency of a stable increase in the proportion of marginal part-time workers in Austria, France and Italy. Meanwhile, a significant increase was found in Portugal from $1.3 \%$ in 2005 to $3.5 \%$ in 2013 and in Spain from 3.3\% to $4.6 \%$. The increase occurred after the global financial crisis. However, in countries where part-time work has become a tradition and accepted by the community, the average share of marginal part-time workers has also been high ranging from 7-12\%. This was found in Britain (7\%), Germany (9\%), Australia (9\%), and Netherlands (12.5\%). Besides European countries, two major countries in East Asia, Japan and Korea also have faced labour market reform as a result of Asian financial crisis. A substantial increase of the proportion of non-standard employees among total employees from $23.8 \%$ in 1990 to $34.1 \%$ in 2008 occurred in Japan. In addition, only $30 \%$ of the Korean workers had regular job in 1999 as the absolute number of non-standard employees has continuously grown from about 3.8 million in 2002 to about 6 million in 2011 (Shin, 2013).

Like in Europe and East Asia, there is an increase as many as 11,197,153 part-time workers in period 2009-2018 in Indonesia. In 2009, $15.4 \%$ of the working population aged 15 years or more were part-time workers. Meanwhile in 2018, the percentage of part-time workers from the same age group became $22.1 \%$. Despite upward trend in total number of part-time workers, observed persistent pattern is that the proportion of women working parttime is always greater than men, ranging from $51-57 \%$. This is similar to Australia where women dominate part-time work from 1980 to 2016 (Cassidy \& Parsons, 2017). In Japan, non-standard employment including part-time work grew from $17 \%$ to $34 \%$ between 1986 and 2008 as consequences of changes in the economic structure, demand fluctuation, advancement of information and communication technology and mainly, employers' declining commitment to the long-term employment relationship to contain labor cost (Asano, Ito, \& Kawaguchi, 2013).

The importance of examining non-standard employment is because it brings disadvantages to the worker. For example, working part time in a variety of literature is associated with low wages, reduced employee benefits, and low job stability (Blank, 1998; Levenson, 2000), especially for women. Working part time is considered as one of work- 
family balancing efforts (de Ruyter \& Warnecke, 2008). In Japan and Korea, the growing of non-standard employment mainly in the form of part-time work generally brought drawbacks to the workers such as low level of wage income, lack of social security provision, and difficult to move from precarious to standard employment as employers resist to provide permanent positions in the face of trying to cut the cost and improve labor flexibility (Cooke \& Jiang, 2017). In Indonesia, the use of NSE is associated to efforts by employers to reduce labor cost and achieve greater flexibility in their utilization of labor (Landau et al., 2015). However, there are few documentations about NSE, particularly marginal parttime workers consdition, since the concept of NSE itself is not obviously defined yet (Serrano et al., 2014). This kind of work arrangements exists not only in informal sector as profile of Indonesia labor market but also in formal sector. Identifying which group in population that is categorized as precarious workers is the first step to provide evidencebased policy in Indonesia labor market. For this reason, this study aims to find the determinant of marginal part-time workers in Indonesian labor market based on their sociodemographic characteristics. This objective is guided by following testable hypotheses that women, the younger, the rural resident, the less educated, and married people are more prone to become marginal part-time worker.

\section{METHOD}

This study used the National Labor Force Survey (NLFS) August 2018 edition. Basically, the survey is conducted twice a year in February and August by BPS-Statistics Indonesia to provide data about current situation of labor in Indonesia. Sample was selected by two-stage stratified sampling for estimation in subdistrict level. The member of selected household aged 15 years old or more will be interviewed about their working activities in the last week and last month.

The crucial indicator used to categorize the workers into full-time and non-full-time (part-time and underemployment) workers is working hours. In this study, based on BPSStatistics Indonesia normal working hours is 35 hours in a week, so the respondent who work for less than 35 hours a week and not looking for another job will be included as parttime worker. In order to distinguish part-time workers as marginal and non-marginal, we constructed a binary variable (mpt) based on hours of work, taking the following values: 1if the individual aged 15 years old has work hours less than 15 hours a week and 0 - if the individual aged 15 years old has work hours of 15-34 hours a week. From that criteria, we obtained 84,765 part-time workers, out of which $24.9 \%$ are marginalized.

The explanatory variables describe socio-demographic characteristic such as sex, age, residence, educational level, and marital status. All interest category in the explanatory variables are given value " 1 " to facilitate interpretation of the econometric result. Sex is defined by values: 0 for males and 1 for females. Age is classified into three groups: 30 years old or younger, 30-49 years old, and 50 years old or older. Residence indicates if respondent lives in an urban area (value 0) or if he/she lives in a rural area (value 1). Educational level is categorized from low to high level as follow: primary education (elementary school or equivalent) or never studied at any school; lower secondary (junior high school or 
equivalent) education; upper secondary (senior high school or equivalent); post-secondary and tertiary educational level. We divided marital status into three categories: never married, married (married1), and divorced or widowed (married2). The last variable is monthly-basis income which is classified as above or below the average income of all parttimers in this study.

We used descriptive and inferential analysis methods to accommodate the purpose of study. The binary logistic regression as econometric method is used when dependent variable is taking only two values $(0 / 1), 1$ indicating the realization of an event. The relationship between the dependent variable and the independent variable is expressed in the form of odds ratio (OR). The modelling of the marginal part-time employment relationship with demographic characteristics is as follows:

$$
\begin{aligned}
\ln \left(\frac{m p t}{1-m p t}\right)= & \beta_{0}+\beta_{1} \text { sex }+\beta_{2} \text { age }_{1}+\beta_{3} \text { age }_{2}+\beta_{4} \text { residence }+\beta_{5} \text { educ }_{1}+\beta_{6} \text { educ }_{2}+\beta_{7} \text { educ }_{3} \\
& +\beta_{8} \text { educ }_{4}+\beta_{9} \text { married }_{1}+\beta_{10} \text { married }_{2}
\end{aligned}
$$

\section{FINDING AND DISCUSSION}

From working population in Sakernas August 2018 as many as 331,346 persons, there are 84,765 workers who are employed part-time and become the sample in this study. The average work hours are 21 hours a week. Overall, a quarter of the part-time workers are classified as marginal with working hours of less than 15 hours per week.

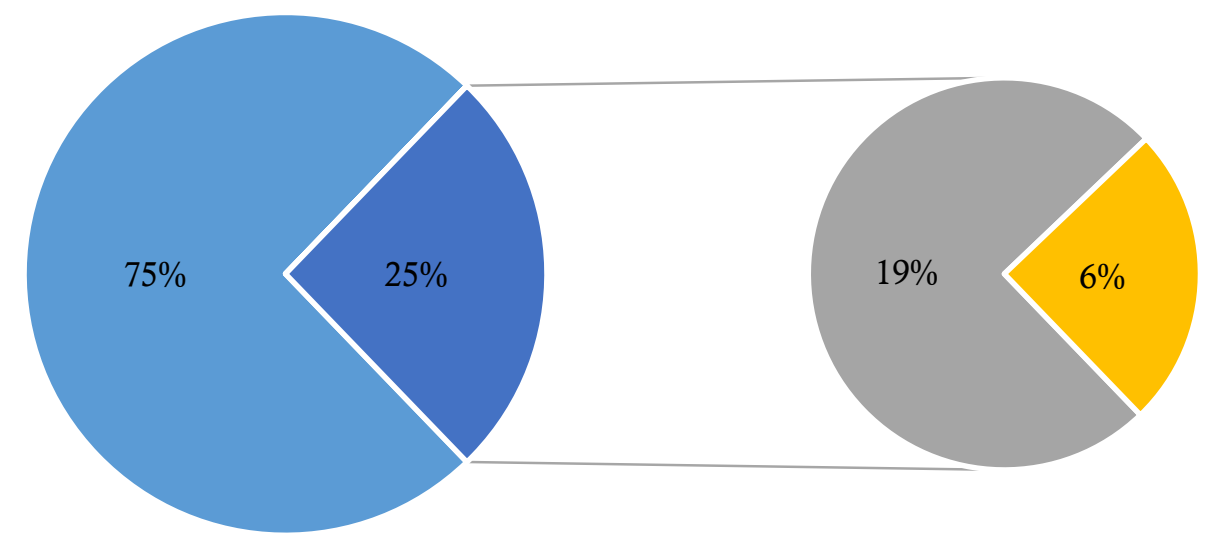

- Non Part-time $\quad$ Substantial Part-time $\quad$ Marginal Part-time

Figure 1. The Proportion of Marginal Part-time Workers

In addition, the average age of part-time workers is 44.8 years old with an average monthly income of Rp.747,589.30, which is below the national minimum wage in 2018 of Rp.2,266,306.00. This feature of part-time workers in Indonesia is very different with casual employment in Australia which typically has $20-25 \%$ higher hourly wage rate than for permanent employee performing the same work. The higher pay rate is aimed to compensate for these workers' lack of employment security and paid annual and sick leave (Messenger \& Wallot, 2013). However, this condition is similar with India where workers 
with lower income is associated with high probability of becoming temporary precarious workers (Sapkal \& Sundar, 2017).

Table 1. Frequency Distribution of Study Variables

\begin{tabular}{lrr}
\hline \multicolumn{1}{c}{ Variable } & Frequency & Percentages (\%) \\
\hline Marginal Part-time & & \\
No & 63,648 & 75.09 \\
Yes & 21,117 & 24.91 \\
\hline Sex & & \\
Male & 36,671 & 43.26 \\
Female & 48,094 & 56.74 \\
\hline Age Group & & \\
$\leq 30$ & 15,115 & 17.83 \\
$30-49$ & 36,346 & 42.88 \\
$\geq 50$ & 33,304 & 39.29 \\
\hline Residence & & \\
Urban & 28,125 & 33.18 \\
Rural & 56,640 & 66.82 \\
\hline Education & & \\
SPrimary & 46,367 & 54.70 \\
Lower Secondary & 15,023 & 17.72 \\
Upper Secondary & 15,580 & 18.38 \\
Post-secondary & 1,686 & 1.99 \\
Tertiary & 6,109 & 7.21 \\
\hline Marital Status & & \\
Never Married & 11,460 & 13.52 \\
Married & 63,807 & 75.28 \\
Divorced/Widowed & 9,498 & 11.21 \\
\hline Total & 84,745 & 100.00 \\
\hline
\end{tabular}

From Table 1 it was found that the distribution of sociodemographic characteristics in the sample of that female (56.74\%), people aged $30-49$ years old (42.88\%), living in rural areas $(66.82 \%)$, educated less than or equal to primary school $(54.70 \%)$ and married (75.28\%) are the majority of marginal part time workers. Similarly, in USA from 1960-2004 the share of women on part-time employment were consistently high, nearly 70 percent (de Ruyter \& Warnecke, 2008). Irawan, et al. (2000) in their report showed that since 1986 until 1999 in Indonesia, share of women employed on jobs which have less than ten hours a week always doubled than men's share. This trend seems unchanged since the result still indicates the predominance of women in marginal part-time employment. This tendency is also quite stable in Korea, as since 2003 the share of women in non-standard jobs remained at $40 \%$ as compared to men's $25 \%$. As of 2014, women are still more likely than men to have nonstandard employment as $71 \%$ of part-time workers and $93 \%$ of domestic workers are women while $61 \%$ of standard workers are men (Kim, 2016).

The over-representative of women in non-standard employment, for this case parttime work, is similar between developed countries and developing countries. It is because part-time work is an alternative way for women to balancing work and family since women that left the labor market for marriage and/or childbearing have difficulty finding 240 
permanent position and are forced to take up temporary jobs when they return to the labor market.

Table 2. Binary Logistic Regression

\begin{tabular}{lrrrr}
\hline \multicolumn{1}{c}{ Variable } & Coefficient & Z-statistics & $\begin{array}{r}\text { Odds } \\
\text { Ratio }\end{array}$ & \multicolumn{1}{c}{$\begin{array}{c}\text { 95\% Conf. } \\
\text { Interval }\end{array}$} \\
\hline Sex: Female & 0.593 & 0.0001 & 1.809 & $1.748-1.872$ \\
Age group: $30-49$ & -0.419 & 0.0001 & 0.658 & $0.623-0.694$ \\
Age group: $\geq 50$ & -0.075 & 0.011 & 0.928 & $0.876-0.983$ \\
Live in rural area & 0.111 & 0.0001 & 1.118 & $1.079-1.158$ \\
Education level: Lower secondary & 0.290 & 0.0001 & 1.336 & $1.278-1.396$ \\
Education level: Upper secondary & -0.073 & 0.002 & 0.930 & $0.888-0.974$ \\
Education level: Post-secondary & -0.463 & 0.0001 & 0.629 & $0.554-0.715$ \\
Education level: Tertiary & -0.942 & 0.0001 & 0.389 & $0.359-0.423$ \\
Married & -0.634 & 0.0001 & 0.530 & $0.500-0.562$ \\
Divorced/widowed & -0.530 & 0.0001 & 0.589 & $0.546-0.636$ \\
\hline Constant & -0.752 & 0.0001 & 0.471 & $0.448-0.496$ \\
\hline Log likelihood & & & & $-45,774.997$ \\
LR chi $^{2}(10)$ & & & & $3,619.19$ \\
Prob $>$ chi & & & & 0.00001 \\
Pseudo R ${ }^{2}$ & & & & 0.0380 \\
\hline
\end{tabular}

Table 2 above indicates that predictors of marginal part-time work are being a woman and living in rural area. These findings support the hypotheses that woman and rural resident are more prone to become marginal part-time worker. Being a woman increase the odds of being marginal part-time worker as much as 1.8 times compared to man. The dominancy of women in part-time employment observed both in developed and developing countries, make part-time work to be highly gendered phenomenon (Hipp, Bernhardt, \& Allmendinger, 2015). It is also found that people who live in rural area experience higher odds of marginal part-time employment than people who live in cities. According to NLFS Report August 2019, agriculture sector still become major industry in Indonesian labor market with $27 \%$ worker employed in agriculture sector. Agriculture sector is typically dominated by casual workers who work only at harvest season. Another characteristic of agriculture sector is that it is located in rural area, so it's reasonable that people living in rural area are more likely to become marginal part-time worker. In addition, McLaughlin and Coleman-Jensen (2008) found that in United States, nonmetro workers are significantly more likely to work part-time hours than central city and suburban workers (odds ratio of 0.92 and 0.94 ).

Other sociodemographic characteristic such as age, education level, and marital status also have significant relationship with marginal part-time employment. People who aged 30-44 years old and 45 years old or older have 34\% and 7\% consecutively lower odds to be marginal part-time worker than people who aged 30 or younger. Therefore, it can be said that younger people are more likely to end up in marginal part-time employment 
relationship. This result shows the same pattern in most countries in Europe from 1996 2011 where marginal part-time employment is characterized by young people aged younger than 30 (Allmendinger, Hipp, \& Stuth, 2013). However, it is interesting to note that the probability of being marginal part-time work gradually decrease as people get older. (AARP Public Policy Institute, 2018) found from Current Population Survey data in United States that the reasons for working part-time among workers aged 65 and older are retirement and/or social security earnings limit.

A lower education level is associated with higher odds of marginal part-time work or in other words the higher education attainment, the lower chance to be marginal part-time worker. As result indicates, worker with tertiary, post-secondary, and upper secondary education have $61 \%, 37 \%$, and $7 \%$ consecutively lower odds of marginal part-time work than primary education or below. Similarly, the study in Germany and France by Marotzke (2019) discovered lower educational level as one of the factors related to greater preferences for part-time employment. On the marital status, the result shows no evidence that married workers are more prevalent in marginal part-time employment. Conversely, the workers with married and divorced/widowed status are less likely to be in marginal part-time work than never married or single workers. It suggested that married and divorced/widowed workers require to find stable jobs to support their families. Consequently, workers with married background are more likely to hold employment with longer work hours ( $>15$ hours a week).

Overall, the result corresponds with study in Asia, such as in Japan by Cooke and Jiang (2017) that stated part-time positions in Japan are frequently filled by mothers, youth, and older workers as cheap labor. In India, even though younger age seems to be more likely to end up in non-standard employment, the determinant of being in precarious work is related. Those workers are characterized by being a woman, with low educational status, low land holding, and holding a minority as well as socially deprived background (Sapkal \& Sundar, 2017).

\section{CONCLUSION}

The increased proportion of part-time workers, especially those who have worked less than 15 hours or so-called marginal part-time workers that occur in developed countries as well as in developing countries, is also observed in Indonesia. The objective of this study is to examine determinants of marginal part-time employment in Indonesia. Based on the results of the study, it was found that women (OR: 1.81; 95\% CI: 1.75-1.87) and people who live in rural areas (OR: 1.12; 95\% CI: 1.08-1.16) are at greater risk of becoming a marginal parttime worker. In terms of education, in general a higher level of education will reduce the risk of being a marginal part-time worker. From this study, it is known that marginal parttime workers are characterized by social and economic vulnerabilities. Since Indonesian labor law does not specifically recognize or regulate part-time work and the law is unclear as to what conditions and benefits should apply to this category of workers, it is important for policymaker and government to ensure they are protected by labor regulation so that their lives can be improved. 


\section{REFERENCES}

AARP Public Policy Institute. (2018). Older Workers and Part-Time Employment [Fact Sheet]. Retrieved from https://www.aarp.org/content/dam/aarp/ppi/2018/part-time-olderworkers.pdf

Allmendinger, J., Hipp, L., \& Stuth, S. (2013). Atypical employment in Europe 1996 2011. Berlin: WZB Discussion Papers.

Asano, H., Ito, T., \& Kawaguchi, D. (2013). Why has the fraction of nonstandard workers increased? A case study of Japan. Scottish Journal of Political Economy, 60(4), 360-389. https://doi.org/10.1111/sjpe.12015

Blank, R. (1998). Contingent Work in a Changing Labor Market. In R. Freeman and P. Gottschalk (eds) Generating Jobs: How to Increase Demand for Less-Skilled Workers, pp. 258-94. New York: Russell Sage Foundation.

BPS-Statistics Indonesia. (2019). Laborer situation in Indonesia August 2019 (BPS Publication No. 04130.1903). Retrieved from https://www.bps.go.id/publication/download.html

Cassidy, N., \& Parsons, S. (2017). The rising share of part-time employment. RBA Bulletin, $19-26$.

Champeau, M., Arsac, M., Pineau, P., \& Denyset, F. (2016). Non-Standard Employment Around the World. In ILO Cataloguing in Publication Data (Vol. 44). International Labour Organization. https://doi.org/https://www.ilo.org/wcmsp5/groups/public/---dgreports/--dcomm/---publ/documents/publication/wcms_534326.pdf

Chattopadhyay, E. G. and P. (2017). Understanding Non-standard Work Arrangements: Using Research to Inform Practice. SHRM-SIOP Science of HR Series. Retrieved from http://www.siop.org/SIOP-SHRM/2017_03_SHRM-

SIOP_Nonstandard_Workers.pdf

Cooke, F. L., \& Jiang, Y. (2017). The growth of non-standard employment in Japan and South Korea: the role of institutional actors and impact on workers and the labour market. Asia Pacific Journal of Human Resources, 55(2), 155-176. https://doi.org/10.1111/1744-7941.12138

de Ruyter, A., \& Warnecke, T. (2008). Gender, non-standard work and development regimes: A comparison of the USA and Indonesia. Journal of Industrial Relations, 50(5), 718-735. https://doi.org/10.1177/0022185608096806

Pfeffer, J. and Baron, J.N. (1988) Taking the Workers Back out: Recent Trends in the Structuring of Employment. In: Staw, B.M. and Cummings, L.L., Eds., Research in Organizational Behavior, Vol. 10, JAI Press, Greenwich, 257-303.

Hipp, L., Bernhardt, J., \& Allmendinger, J. (2015). Institutions and the prevalence of nonstandard employment. Socio-Economic Review, 13(2), 351-377. https://doi.org/10.1093/ser/mwv002

Houseman, S., \& Osawa, M. (2003). Nonstandard Work in Developed Economies: Causes and 
Jurnal Economia, 16(2), October 2020, 236-244

Consequences. Michigan: W.E. Upjohn Institute for Employment Research. https://doi.org/10.17848/9781417505326

Irawan, P. B., Ahmed, I., \& Islam, I. (2000). Labour Market Dynamics in Indonesia: Analysis of 18 Key Indicators of the Labour Market 1986-1999. In International Labour Organization. Jakarta.

Kim, H. J. (2016). Three dualization processes in Korea: The labor market, welfare policy, and political representation. Development and Society, 45(2), 297-326. https://doi.org/10.21588/dns.2016.45.2.005

Landau, I., Mahy, P., \& Mitchell, R. (2015). The regulation of non-standard forms of employment in India, Indonesia and Viet Nam. (63). Retrieved from http://eprints.soas.ac.uk/20898/1/wcms_414583.pdf

Levenson, A. (2000). Long-Run Trends in Part-Time and Temporary Employment: Toward an Understanding. In D. Neumark (ed.) On the Job, pp. 335-97. New York: Russell Sage Foundation.

Marotzke, P. (2019). The rise of part-time work: A German-French comparison (No. 20). Frankfurt: Deutsche Bundesbank.

McLaughlin, D. K., \& Coleman-Jensen, A. J. (2008). Nonstandard employment in the nonmetropolitan United States. Rural Sociology, 73(4), 631-659. https://doi.org/10.1526/003601108786471558

Messenger, J. C., \& Wallot, P. (2013). INWORK Policy BriefNo . 7 The Diversity of "Marginal " Part-Time Employment. (7), 1-12.

Sapkal, R. S., \& Sundar, K. R. S. (2017). Determinants of precarious employment in India: An empirical analysis. Precarious Work: Research in Th Sociology of Work, 31, 335-361.

Serrano, M. R., Marasigan, M. L. C., \& Pupos, V. E. V. (2014). Between flexibility and security: The rise Of non-standard employment in selected ASEAN countries. Retrieved from http://library.fes.de/pdf-files/bueros/singapur/10792.pdf

Shin, K. (2013). Economic crisis, neoliberal reforms, and the rise of precarious work in South Korea. American Behavioral Scientist, 57(3), 335-353. https://doi.org/10.1177/0002764212466241 